\title{
Derivacija glagola sa osnovama stranog porekla u srpskom jeziku u svetlu (ne)jasne diferencijacije između srpskog i hrvatskog standarda ${ }^{\mathrm{I}}$
}

\author{
Mirela Ivanić, Jelena Perišić \\ Faculty of Philosophy, Department of Serbian Language and Linguistics, Novi Sad \\ mirelaivanic25@gmail.com \\ jelenaperisic91@hotmail.com
}

Predmet ovog rada su glagoli čije su tvorbene osnove uglavnom stranog porekla i na njih se prilikom derivacije u srpskom jeziku dodaju sufiksi -ova-, -isa- ili -ira-. Cilj je provera usklađenosti utvrđenog stanja sa srpskim standardom, odnosno da li se derivacija vrši u skladu sa utvrđenim normama srpskog standardnog jezika, ima li uticaja hrvatskog standarda i da li uopšte postoji jasna granica među dvama standardima u ovom njihovom segmentu. Najpre će se predstaviti norme koje propisuju savremeni srpski i hrvatski jezik, a zatim sa njima uporediti stanje utvrđeno na osnovu rezultata analize. Rezultati će se uporediti i sa ranijim zaključcima u vezi sa ovom temom, kako bismo utvrdili da li je došlo do nekih promena. Korpus za analizu čine informativni tekstovi iz srpskih nedeljnih novina.

Ključne reči: glagoli, strane osnove, sufiksi, derivacija, srpski i hrvatski standard

1 Ovaj rad je deo projekta Standardni srpski jezik: sintaksička, semantička i pragmatička istraživanja (178004), koji finansira Ministarstvo prosvete, nauke i tehnološkog razvoja Republike Srbije. 
The Derivation of the Verbs with Generative Bases of Foreign Origin in the Serbian Language in the Light of (Un)clear Differentiation between the Serbian and Croatian Standard

The paper deals with verbs whose generative bases are mostly of foreign origin and their derivatives are added suffixes -ova-, -isaor -ira- from Serbian. The aim is to check the compliance of the established situation with Serbian standards, that is, whether the derivation is performed in accordance with established norms of Serbian standard language, is there any influence of Croatian standards and whether there is a clear distinction between these two. At first, we will introduce the norms prescribed by the contemporary Serbian and Croatian languages and then compare them with the situation established on the basis of the analysis results. The results will then be compared with earlier conclusions on this subject in order to determine whether there have been any changes. The corpus for analysis consists of informative texts from a Serbian weekly magazine.

Key words: verbs, foreign bases, suffixes, derivation, Serbian and Croatian standard

\section{Uvod}

Adaptirani glagoli iz drugih jezika predstavljaju neizostavan deo leksičkog sistema gotovo svakog jezika, pa tako i srpskog. Načini tvorbe takvih glagola i najfrekventniji sufiksi pomoću kojih se izvode značajni su i za izvorne govornike srpskog jezika, ali i za one koji srpski jezik uče kao strani. Stoga, predmet ovog rada jesu glagoli čije su tvorbene osnove uglavnom stranog porekla i na njih se prilikom derivacije u srpskom jeziku dodaju sufiksi -ova-, -isa- ili -ira-.

Cilj ovoga rada jeste provera usklađenosti utvrđenog stanja sa srpskim standardom, odnosno stepen varijabilnosti, tj. stabilnosti u procesu tvorbe glagola iz navedene grupe, i konačno, ispitivanje postojanja jasne granice među dvama standardima u ovom njihovom segmentu.

U skladu sa postavljenim ciljem, najpre će se predstaviti norme koje propisuju savremeni srpski i hrvatski jezik, a zatim sa njima uporediti stanje utvrđeno na osnovu rezultata analize. Rezultati istraživanja će se uporediti i sa ranijim zaključcima u vezi sa ovom temom - iz perioda posto- 
janja srpskohrvatskog jezika i neposredno nakon njegove podele na srpski i hrvatski standard, kako bismo utvrdili da li je došlo do nekih promena.

Korpus za analizu čine informativni tekstovi iz srpskih nedeljnih novina. U pitanju su Nedeline informativne novine (NIN), tačnije četiri broja ovog nedeljnika: od 14. jula (broj 3420), 21. jula (broj 3421), 25. avgusta (broj 3426) i 1. septembra 2016. godine (broj 3427).

Što se metodologije tiče, u radu će se koristiti komparativna, analitička i statistička metoda. Komparativna metoda će biti zastupljena prilikom upoređivanja dvaju standarda (srpskog i hrvatskog), kao i prilikom poređenja rezultata istraživanja sa pravilima jednog i drugog jezika, ali i sa ranijim zaključcima u vezi sa ovom temom. Analitička metoda će se koristiti prilikom analiziranja korpusa, a statistička prilikom prikazivanja rezultata - brojčani i procentualni podaci u vezi sa zastupljenošću sufiksa u korpusu, kao i u vezi sa poreklom osnove od koje su glagoli derivirani.

Teorijski okvir čine srpske i hrvatske gramatike, radovi eminentnih autora povezani sa temom ovog rada, kao i rečnici jednog i drugog jezika. Osnovni izvor podataka o poreklu osnova i propisanim oblicima glagola u srpskom jeziku predstavlja Leksikon stranih reči i izraza Milana Šipke i Ivana Klajna.

\section{Derivacija glagola sa osnovama stranog porekla u ranijim istraživanjima}

Pre nego što se pristupi istraživanju, osvrnućemo se na ranije teorijske postavke, istraživanja i rezultate dobijene na materijalu srpskog/hrvatskog, odnosno srpskohrvatskog jezika, u vezi sa ovim problemom. Istraživana problematika izložiće se tako što će se sagledati normativni status posmatranih glagola u preskriptivnim relevantnim gramatikama (Hrvatska gramatika, Gramatika srpskog jezika) i priručnicima standardnog srpskog i hrvatskog jezika, s ciljem da se ustanovi stepen poklapanja, odnosno razlikovanja registra posmatranih glagola. Da bi se upotpunila slika mogućeg diferenciranja, predstaviće se osnovni rezultati istraživanja koji su za predmet imali tvorbu glagola s osnovama stranog porekla.

U gramatikama se glagolski sufiksi navode najčešće bez infinitivnog nastavka -ti i sve u želji da se sufiksi jasnije odvoje od infinitivnog nastavka i da se bolje diferenciraju među sobom. Međutim, ovakvu logiku gramatičari nikad ne primenjuju na druge vrste reči. Tako, na primer, kako Klajn navodi, u gramatici Stanojčić-Popović $(2002,160)$ skrivati, zagrađi- 
vati, zadobivati dati su kao primeri za sufiks -iva-, „bez napomene da to -iva- kod jednih glagola ostaje i u prezentu, dok kod drugih prelazi u -uje-“ (Klajn 2003, 323). U našem korpusu evidentni su primeri različitih glagolskih vidova, pa u tom smislu možemo govoriti o sufiksima za perfektivizaciju i imperfektivizaciju. Kako Klajn kaže, gramatike ih tretiraju kao i ostale sufikse, s tim što ih svrstavaju pod „glagole izvedene iz glagola“. Samim tim se nameće pitanje da li je nesvršeni glagol zaista „nova“ reč u odnosu na svršeni. Srpska leksikografska praksa pokazuje da to nije tako jer Rečnik Matice srpske (RMS), kao i većina drugih rečnika, upućuje na nesvršeni, odnosno učestali glagol u odnosu na odgovarajući svršeni. Potvrđuje se da svršeni i nesvršeni glagoli nisu posebne lekseme, budući da se međusobno ne razlikuju po značenju, nego samo po gramatičkom obeležju aspektualnosti. Zanimljivo je pogledati kako ovom problemu pristupa Hrvatska gramatika (Barić i dr. 1997). U njoj su vidski parovi obrađeni u dva poglavlja (Morfologija i Tvorba riječi). Upravo u prvom poglavlju nailazimo na termine perfektivizacija i imperfektivizacija, koja se smatra jednom od mehanizama tvorbe, i to takav kojim se generišu različiti tipovi nesvršenih glagola od kojih jedan ima sufiks -a- (sjesti - sjedati) (Barić i dr. 1997, 372).

O sufiksima koji su predmet ovog rada pisao je Petar Skok pedesetih godina prošlog veka. Ovaj autor iznosi da su, od triju sufiksa, dva stranog porekla. Naime, -isati, kojem je središte Beograd, potiče od grčkog aorista - od grčkih denominala na -izo, aorist -isa. Mišljenje autora je da je ovaj sufiks u turcizmima, isto kao i u bugarski, i u naš jezik ušao preko cincarskog govora (u cincarskom se dodaje grčki denominalni sufiks -izo, aorist -isa na turske glagolske osnove) i balkanska je jezička pojava. Na zapadu, čije je središte Zagreb, ustalio se sufiks -irati od nemačkog infinitiva na -ieren, a taj od francuskog infinitiva na -er koji potiče od latinskog -are ili od franscuskog na -ir, a on vodi poreklo od latinskog -ire, dok je sufiks -ovati naša baština iz praslovenskog jezika (Skok 1955-56). Ivan Klajn (2003, 339) slaže se sa Skokom što se porekla sufiksa tiče, s tim što za sufiks -isa(ti) navodi da je grčkog porekla, ali se u srpskoj derivatologiji svrstava pre u domaće nego u strane sufikse. Ističe da se on upotrebljava sa mnogim stranim glagolskim osnovama koje u hrvatskom (katkad alternativno i u srpskom) imaju -irati, ali dolazi i na domaće osnove (ugljenisati), u odomaćenim grecizmima (mirisati, metenisati), kao i u starim turcizmima (begenisati, kaldrmisati). O poreklu ovih sufiksa govori i M. Jocić i slaže se sa navedenim autorima. Dodaje da se sufiks -isa- prvi put javlja na istoku naše jezičke teritorije u pozajmicama iz grčkog jezika u XII veku, počev od XVII veka 
sve više se vezuje za turske pozajmice u srpskohrvatskom jeziku, u XVIII i XIX veku veoma je intenzivan prodor turskih pozajmica sa ovim sufiksom, a u XX veku se javlja i u tzv. evropskim glagolima. Sufiks -ira- u naš jezik ušao je u XVII veku i najveća frekvencija njegovog javljanja u srpskohrvatskom jeziku karakteristična je za XX vek, naročito za savremenu jezičku situaciju. U različitim varijantama ovaj sufiks postoji i u makedonskom, bugarskom, ruskom, skandinavskim jezicima, latinskom, francuskom i nemačkom, što mu daje izuzetnu vitalnost i omogućava njegovu visoku frekvenciju u rečima internacionalnog karaktera (Jocić 1970, 121-122).

Skok napominje da je i Vuk tolerisao sufiks -irati i prenosi stav Maretića, čija se gramatika drži Vukovog jezika, da -isati nije „nimalo srpskije“ od -irati, ali napominje da Maretić nije vodio računa o tome da sufiks -isati nije moguće zameniti sa -irati u već navedenim slučajevima kao što su turcizmi, čisti grecizmi i sl. (Skok 1955-56, 41). Skok takođe navodi da je odavno kod „čistilaca jezika“ postojala tendencija da se strani glagolski sufiksi -isati i -irati zamene domaćim denominalnim glagolskim sufiksom -ovati, koji potiče iz praslovenskog doba, a bio je na svakom stepenu našeg jezičkog razvitka živ i plodan, pa se pojavila težnja da mu se ista funkcija osigura i za aktuelni jezički razvitak. Prema Skoku, postoji izvesna razlika između ovog denominalnog sufiksa i stranih sufiksa -isati i -irati u pogledu denominalnosti, jer su druga dva retko kada čisti denominali. To je slučaj samo onda kad od stranih glagola, koje oni kod nas zamenjuju, već postoje imenice koje se poklapaju sa korenom glagola (npr. kod respektirati već postoji imenica respekt). U velikoj većini slučajeva osnovne imenice glagola na -isati i -irati imaju apstraktne strane sufikse (npr. korupcija uz korumpirati) i u tim bi se slučajevima moglo govoriti samo o logičkoj denominalnosti u izvođenju na -isati i -irati, nikako o gramatičkoj gde se traži istovetnost imenice i glagolske osnove. Međutim, u semantičkom pogledu, sufiks -ovati se u potpunosti poklapa sa sufiksima -isati i -irati i označava da je imenička osnova dobila značenje glagola, odnosno glagolske radnje. Zbog toga je i danas lako stvarati glagole na -ovati od imenica, bilo konkretnog bilo apstraktnog značenja. Na osnovu toga Skok (Skok 1955-56, 42) zaključuje da se ne može izvesti nikakvo određeno pravilo kada se mora upotrebljavati -ovati, kada -irati, a kada -isati.

Što se situacije u hrvatskom standardu tiče, Hrvatska gramatika (Barić i dr. 1997) naglašava da se sufiksom -ova- u hrvatskom jeziku tvore glagoli od imenica, kao i da se sufiksom -ira- tvore glagoli uglavnom od imenica 
stranog porekla ili od stranih glagola: adresirati, frazirati, lakirati, modelirati, demonstrirati, filozofirati.

Jernej, navodeći dosta starih primera iz Rječnika Jugoslovenske akademije znanosti i umetnosti (Rječnika hrvatskoga ili srpskoga jezika-RJAZU), ističe da se prilikom tvorbe novih glagola sufiksom -ira- javljaju mnoge alternacije (k>c: muzicirati, gimnasticirati, evocirati, locirati, provocirati) i retko dolazi posle vokala (praktično samo u kreirati, evoluirati, fluktuira$t i$, situirati, perfektuirati i dr). Najveći deo glagola na -irati čine izvedenice od imenica stranog porekla. Motivacioni odnosi su neprozirni u tim primerima, te razvrstavanje po semantičkim grupama nije relevantno (Jernej 1959, 31-40).

Milivoj Pavlović u jednom svom kratkom radu s kraja prve polovine 2o. veka iznosi zapažanje da je završetak -irati dobio vrlo široku primenu, naročito kod glagola stranog porekla ili onih koji su izvedeni od stranih reči, obično nemačkih ili primljenih u nemačkoj formi (npr. kreirati, marširati, revidirati). Smatrao je da je borba ovog završetka sa -ivati i -isati interesantna i da bi se tu mogao donekle ustanoviti geografski odnos, a do izvesne mere i jedna vrsta reparticije (Pavlović 1940, 82).

Skok na osnovu brojnih primera postavlja pravilo da se na istoku jezičke teritorije pokazuje tendencija vezivanja sufiksa -isati za latinske, ređe za grčke, a još ređe za francuske internacionalne reči. Svi ti primeri na zapadu jezičke teritorije imaju nastavak -irati, a jedino u turcizmima nije moguće na zapadu -isati zameniti sa -irati. On primećuje da se na osnovu RistićKangrginog rečnika dobija utisak da je sufiks -irati prodro i u Srbiju i da tu nadmašuje oba druga sufiksa, kao i da beogradski jezički osećaj nikako ne pušta beskrajno generalizovanje sufiksa -isati na štetu sufiksa -irati (Skok 1955-56, 39-40).

O istoj problematici govori Mihailo Stevanović u svom radu Neke leksičko-stilske razlike, a ne jezičke varijante iz 1964-65. godine, gde se bavi problemom nastavaka prilikom izvođenja glagola od osnova stranog porekla. Iznosi da su među izvedenim rečima nejednako građenim kod Hrvata i Srba najčešće navođeni glagoli stranog porekla s nastavcima -ovati, -irati i -isati, tipa: operirati-operisati i rehabilitirati-rehabilitova$t i$, kao i to da je:

s pravom isticano [...] da su glagoli u prvom navedenom obliku primljeni kod nas uglavnom iz nemačkog jezika, i s nastavkom za osnovu -ir, pa im je dodat samo domaći završetak -ati (operirati, rehabilitirati) - pretežno kod Hrvata, a u drugom su obliku prim- 
ljeni s nastavkom za osnovu -is, koji je grčkog porekla, i na koji je dalje dodat isti završni deo -ati (operisati), ili je uzet samo opšti deo, na koji se dodavao ne samo isti završni nastavak već i domaći nastavak za osnovu -ov (rehabilitovati) - pretežno kod Srba. Ali ni ovde nemamo prvo samo kod Hrvata, a drugo i treće samo kod Srba, već se, kako je dobro poznato, veliki broj glagola na -irati, kao što su: gravitirati, deklinirati, finansirati, oponirati i dr. i kod Srba upotrebljava isključivo u obliku s ovim nastavkom; drugi se upotrebljavaju naporedo, s nastavkom -irati i nastavkom -isati, ili s nastavkom -irati i domaćim nastavkom -ovati (Stevanović 1964-65, 202-203).

Mirjana Jocić se u svom istraživanju iz 197o. godine bavila glagolima sa sufiksima -isa-, -ira-, -ova- u savremenom srpskohrvatskom jeziku, sa ciljem da se na bazi postojećih rečničkih izvora savremenog srpskohrvatskog jezika prezentuje što potpuniji materijal u vezi sa ovim sufiksima i na osnovu toga razmotri i prokomentariše frekventnost, kao i neki kulturno-istorijski, etimološki, semantički i morfofonološki elementi javljanja ovih sufiksa u našem jeziku. Iz prezentovanog materijala vidi se da, mada je evidentan hronološki prioritet sufiksa -ova-, odnosno -isa-, ipak postoji izrazita predominacija oblika glagola sa sufiksom -ira- i -izira- nad oblicima sa sufiksom -ova- i -isa-. Kod glagola starijeg porekla retka je paralelna upotreba sufiksa, dok je kod glagola novijeg porekla znatno češća, naročito sufiksa -izira : -izova. Uočljiva je ograničenost reči turskog porekla na jedan sufiks - gotovo uvek -isa-, i domaćih reči gotovo uvek na -ova-. Sufiks -ovadobijaju i mnogi glagoli stranog porekla: driblovati, linčovati, organizova$t i$, apelovati, letovati. S druge strane, sufiks -isa- javlja se u rečima koje nisu grčkog i turskog porekla: definisati, legitimisati, hohštaplerisati; -ira- se nalazi i u sloju internacionalne leksike poreklom iz grčkog, i, sasvim retko, turskog.

Ne bi se, prema tome, mogla izvršiti striktna reparticija sufiksa prema etimološkom kriteriju prema kojoj bi sufiksi -isa- i -irabili ograničeni samo na reči stranog porekla, a -ova- na reči domaćeg porekla, odnosno prema kojoj bi sufiks -isa- bio ograničen samo na reči grčkog i turskog porekla, a sufiks -ira- na reči latinskog, nemačkog, francuskog, engleskog i italijanskog porekla. (Jocić 1970, 168) 
Na samom kraju autorka iznosi zaključak da je ekspanzija sufiksa -irau savremenom srpskohrvatskom jeziku neosporna; sufiks -isa- u mnogo manjoj meri ima, takođe, tendenciju širenja, ali u obrazovanjima novijeg tipa koja ne spadaju u književni jezik. Mada je po broju oblika zastupljenih u materijalu sufiks -ova- znatno frekventniji od sufiksa -isa-, ovaj sufiks nije tako karakterističan za nova građenja, a sve to treba posmatrati kao ujednačavanje na balkanskoj osnovi (sufiks -isa-) i kao vid izvesne internacionalne jezičke integracije (sufiks -ira-). Dalje, autorka zapaža da je jezik tadašnjih književnih dela, publicistike, radija, televizije, govorni i šatrovački jezik, značajan izvor novih glagola sa sufiksima -isa- i -ira-, tim pre što se upotreba ova dva sufiksa (pre svega -isa-) sve više koristi za postizanje naročitosti izraza. Na osnovu materijala se može potvrditi postojanje relevantne različitosti u upotrebi tri razmatrana sufiksa na istoku i na zapadu naše jezičke teritorije.

Noviji materijal sa sufiksima -ira-, -isa- i -ova- pokazuje tendenciju, gde god ne deluje neki od pomenutih ograničavajućih faktora, naporednog javljanja dva odnosno tri sufiksa kod glagola iste derivacione osnove. Visoka frekvencija upotrebe sifiksa -ira- i -isa-, i njihova upotreba za obrazovanje glagola od domaćih osnova, svedoči o odomaćivanju, može se reći potpunom usvajanju ovih sufiksa u srpskohrvatskom jeziku. Tendencija 'prevođenja' sufiksa -ira- i -isa- sufiksom -ova- skoro da više i ne postoji. Neophodno da se prisustvo stranih reči sa ovim sufiksima, i sami ti sufiksi, tretiraju kao vid bogaćenja srpskohrvatskog jezika, a ne kao 'strano telo' kojega se treba dosledno oslobađati (Jocić 1970, 168-174).

Spiskovi glagola deriviranih sufiksom -ova- koje čitamo u radovima Ristić-Cvijić (1970, 134-144) beleže i zastarele oblike, koji bi se za današnji jezik morali drugačije podeliti (diktovati, riskovati), kao i varijante koje su samo hrvatske (emitirati, kondenzirati, suspendirati i sl.). Takvih najviše ima internacionalnih latinizama, potom slede reči iz francuskog (angažovati, rezonovati), stariji germanizmi (pelcovati, dihtovati, štelovati), kao i sve veći upliv anglicizama počev od 20. veka (startovati, driblovati, piknikovati, flertovati).

B. Tošovićprenosi stavSlavka Vukomanovića, iznet u radu Srpskohrvatski standardni jezik, njegove varijante i ime iz 1987. godine, u kom je pratio izlaganja političara iz Srbije i Hrvatske, da se razlike između srpske i hrvatske varijante srpskohrvatskog jezika svode na svega nekoliko stavki, od kojih je jedna i upotreba sufiksa -ira- koji je dosta produktivan (Tošović-Wonish 2011, 624). Takođe, Tošović ukratko iznosi i mišljenje Lalića da: 
se leksičke razlike između dviju varijanti ne tiču nigdje sistema građenja riječi ili nekog drugog jezičkog principa, s tim što izuzetak čine dva slučaja: 1. glagoli sa sufiksima -isa, -ova i -ira (Hrvati češće upotrebljavaju glagole sa -ira, dok Srbi koriste sva tri) [...] (Tošović-Wonish 2011, 699).

Isti autor u okviru istog zbornika u svom radu Dvjesta godina srpskih pogleda na jezik Srba, Hrvata, Bošnjaka/Muslimana i Crnogoraca iz 2011. daje sumaran prikaz svih dotadašnjih istraživanja i pogleda i konstatuje da se na tvorbenom planu ukazuje na nejednaku zastupljenost glagolskih sufiksa -isa- i -ira-. Slaže se sa konstatacijom Pavla Ivića da „između dve varijante nema glasovnih i gramatičkih suprotnosti, slobodnih od leksičkih ograničenja, sa jednim izuzetkom - dvostrukim izgovorom u obliku ekavice i ijekavice“ (Tošović-Wonish 2011, 740).

\section{Korpus i hipoteze istraživanja}

Kao što je u uvodnom delu već navedeno, korpus za ovo istraživanje čine tekstovi iz Nedeljnih informativnih novina, tačnije četiri broja ovog nedeljnika. U obzir su došli svi objavljeni tekstovi, među kojima su u najvećem procentu zastupljeni tekstovi srpskih autora. Postoji i nekoliko tekstova hrvatskih autora, koji su za ovo istraživanje značajni jer predstavljaju ilustraciju sličnosti i razlika među standardima dvaju jezika. Iz tekstova su ekscerpirani glagoli u svim ličnim glagolskim oblicima, infinitivu, glagolski prilozi, kao i glagolski pridevi u sklopu složenih glagolskih oblika, a u radu su ti glagoli prikazani u svom osnovnom obliku (infinitivu).

$\mathrm{Na}$ osnovu uvida u relevantnu literaturu pretpostavlja se da se ne može povući jasna granica između srpskog i hrvatskog standarda kada je u pitanju derivacija glagola sa osnovama stranog porekla i posmatranim sufiksima, pa će se javiti glagoli koji se deriviraju uz pomoć istog sufiksa (-ira-) u oba jezika. Takođe, budući da se radi o tekstovima čiji su autori pretežno izvorni govornici srpskog jezika, očekuje se da će prevagnuti upotreba domaćeg sufiksa -ova- i odomaćenog -isa- nad sufiksom -ira-, bar u onim primerima koji ilustruju razlike među jezicima. S druge strane, s obzirom na to da je u dosadašnjim istraživanjima primećena ekspanzija sufiksa -ira- u srpskom jeziku, očekivani su i takvi primeri koji će odslikati odstupanje od norme standardnog srpskog jezika. 


\section{Analiza i rezultati istraživanja}

Pošto smo predstavili teorijska utemeljenja ovog rada i dali preglede ranijih istraživanja koja su u neposrednoj vezi sa našim ispitivanim sufiksima, opisali korpus i izneli osnovne hipoteze, prelazimo na analizu naše ekscerpirane građe. Ukupno je izdvojen 241 glagol deriviran sufiksima -isa-, -ira- i -ova-. Fond tih glagola predstavićemo u vidu tabele:

\begin{tabular}{|c|c|c|c|}
\hline - & -ova- & -isa- & -ira- \\
\hline grč. & $\begin{array}{l}\text { demokratizovati, ho- } \\
\text { mogenizovati, kan- } \\
\text { onizovati, kritikovati, } \\
\text { tematizovati }\end{array}$ & $\begin{array}{l}\text { fotografisati, katego- } \\
\text { risati, koreografisa- } \\
\text { ti, okarakterisati, par- } \\
\text { anoisati }\end{array}$ & $\begin{array}{l}\text { apostrofirati, orkestrirati, para- } \\
\text { frazirati }\end{array}$ \\
\hline lat. & $\begin{array}{l}\text { apelovati, asimilova- } \\
\text { ti, deponovati, depro- } \\
\text { vincijalozovati, desta- } \\
\text { bilizovati, diskutovati, } \\
\text { diskvalifikovati, edu- } \\
\text { kovati, emitovati, fab- } \\
\text { rikovati, falsifikovati, } \\
\text { identifikovati, ilustro- } \\
\text { vati, institucionalizo- } \\
\text { vati, iskomplikovati, } \\
\text { kandidovati, kombi- } \\
\text { novati, komplikova- } \\
\text { ti, kompromitovati, } \\
\text { konkretizovati, kon- } \\
\text { sultovati, korigovati, } \\
\text { kvalifikovati, okvali- } \\
\text { fikovati, praktikovati, } \\
\text { pretendovati, prezen- } \\
\text { tovati, profesionalizo- } \\
\text { vati, radikalizovati, } \\
\text { reflektovati, relativ- } \\
\text { izovati, resocijalizo- } \\
\text { vati, suspendovati, tri- } \\
\text { jumfovati, unifikovati, } \\
\text { zakomplikovati }\end{array}$ & $\begin{array}{l}\text { afirmisati, artikulisa- } \\
\text { ti, deflorisati, deter- } \\
\text { minisati, dezinfor- } \\
\text { misati, eliminisati, } \\
\text { formulisati, funkcion- } \\
\text { isati, generisati, igno- } \\
\text { risati, informisati, in- } \\
\text { spirisati, integrisati, } \\
\text { intervenisati, izmanip- } \\
\text { ulisati, kanalisati, ko- } \\
\text { mentarisati, koncen- } \\
\text { trisati, konkurisati, } \\
\text { konstituisati, kon- } \\
\text { struisati, manipulisa- } \\
\text { ti, profunkcionisati, } \\
\text { prokomentarisati, pro- } \\
\text { movisati, reformisati, } \\
\text { regulisati, rekonstrui- } \\
\text { sati, spekulisati, stim- } \\
\text { ulisati, subvencionisa- } \\
\text { ti, sugerisati, tolerisati, } \\
\text { transformisati }\end{array}$ & $\begin{array}{l}\text { abolirati, aktivirati, animira- } \\
\text { ti, anulirati, asocirati, demoli- } \\
\text { rati, demonstrirati, diktira- } \\
\text { ti, dimenzionirati, doktorirati, } \\
\text { dominirati, donirati, egzistira- } \\
\text { ti, eksplodirati, emigrirati, fik- } \\
\text { sirati, fokusirati, generirati, il- } \\
\text { ustrirati, inicirati, inscenirati, } \\
\text { insinuirati, insistirati, intenzi- } \\
\text { virati, interpretirati, investirati, } \\
\text { iziritirati, kastrirati, katapulti- } \\
\text { rati, kolaborirati, komunici- } \\
\text { rati, konotirati, konzumirati, } \\
\text { kooptirati, kreirati, kulmini- } \\
\text { rati, likvidirati, locirati, mag- } \\
\text { istrirati, navigirati, negirati, } \\
\text { nervirati, preferirati, prejudi- } \\
\text { cirati, procesuirati, prolongi- } \\
\text { rati, propagirati, redistribui- } \\
\text { rati, relaksirati, restaurirati, } \\
\text { restrukturirati, sanirati, signal- } \\
\text { izirati, stagnirati, strukturirati, } \\
\text { studirati, sublimirati, tangira- } \\
\text { ti, tempirati, testirati, urgirati, } \\
\text { uzurpirati, varirati }\end{array}$ \\
\hline
\end{tabular}




\begin{tabular}{|c|c|c|c|}
\hline- & -ova- & -isa- & -ira- \\
\hline fr. & $\begin{array}{l}\text { angažovati, atakova- } \\
\text { ti, bombardovati, de- } \\
\text { batovati, demantovati, } \\
\text { diskreditovati, doka- } \\
\text { pitalizovati, formal- } \\
\text { izovati, garantovati, } \\
\text { interesovati, izolova- } \\
\text { ti, konstatovati, legal- } \\
\text { izovati, mobilizovati, } \\
\text { modernizovati, nor- } \\
\text { malizovati, organizo- } \\
\text { vati, prodefilovati, pro- } \\
\text { testvovati, realizovati, } \\
\text { regrutovati, rezono- } \\
\text { vati, rizikovati, stabi- } \\
\text { lizovati }\end{array}$ & $\begin{array}{l}\text { demoralisati, iskris- } \\
\text { talisati, karakterisati, } \\
\text { kontrolisati, motivisa- } \\
\text { ti, neutralisati, pro- } \\
\text { filisati }\end{array}$ & $\begin{array}{l}\text { analizirati, ažurirati, balansi- } \\
\text { rati, bazirati, dezavuirati, ese- } \\
\text { jizirati, etablirati, finansirati, } \\
\text { kopirati, maltretirati, maski- } \\
\text { rati, minirati, montirati, plan- } \\
\text { irati, plasirati, precizirati, ran- } \\
\text { girati, realizirati, reprizirati, } \\
\text { revoltirati, servirati, servisira- } \\
\text { ti, simulirati, šokirati, trenirati, } \\
\text { tretirati, umarširati, volontira- } \\
\text { ti, zamaskirati }\end{array}$ \\
\hline nem. & $\begin{array}{l}\text { lumpovati, prošverco- } \\
\text { vati, reagovati, šver- } \\
\text { covati }\end{array}$ & definisati, referisati & $\begin{array}{l}\text { blokirati, diplomirati, distanci- } \\
\text { rati, dozirati, formirati, gusti- } \\
\text { rati, isprovocirati, kompletirati, } \\
\text { lavirati, odblokirati, okupirati, } \\
\text { pozicionirati, profitirati, provo- } \\
\text { cirati, reaktivirati, renovirati, } \\
\text { rezultirati }\end{array}$ \\
\hline engl. & $\begin{array}{l}\text { detektovati, dopingo- } \\
\text { vati, monopolizovati, } \\
\text { startovati }\end{array}$ & intervjuisati & $\begin{array}{l}\text { aplicirati, implementirati, lim- } \\
\text { itirati, lobirati, targetirati }\end{array}$ \\
\hline al. & & & intrigirati, skicirati \\
\hline
\end{tabular}

U tabeli je pored ekscerpiranih glagola naznačeno i poreklo glagolske osnove, tj. jezik iz kog je ona potekla ili preuzeta, naravno sa podrazumevanim morfofonološkim adaptacijama u srpskom jeziku. Iz tabele možemo da iščitamo sledeće relevantne podatke:

Strani sufiks -ira- pokazuje najveću distributivnost kad su osnove stranog porekla u pitanju - 119 evidentiranih glagola. Najčešće dolazi na osnove latinskog porekla - 63, što je u procentima 52,94\%, potom na osnove poreklom iz francuskog - $29(24,37 \%)$ i nemačkog - 17 (14,39\%), dok su malobrojnije osnove iz engleskog - $5(4,2 \%)$, grčkog - $3(2,52 \%)$ i italijanskog porekla - 2 (1,68\%). U analiziranoj građi pronašli smo zanimljive primere glagola kod kojih, prema pravilima navedenim kod M. Šipke i I. Klajna, umesto ovog sufiksa fungiraju druga dva (-isa- i -ova-) ili je dozvoljena naporedna upotreba. Navedeni glagoli se u analiziranoj građi gotovo dosledno javljaju sa sufiksom -ira-, kao na primer analizirati : analizovati, dezavuirati : dezavuisati, kolaborirati : kolaborisati, navigirati : navigati, signalizirati : signalizovati, sublimirati : sublimisati. Kao što se vidi iz pregleda literature, upravo 
su svi ovi primeri sa -ira- karakteristični prevashodno za hrvatski standard, te se kao hrvatski uticaj mogu sporadično javiti i u srpskom jeziku, iako nisu potvrđeni u literaturi (Veliki rečnik stranih reči i izraza).

Opšteslovenski sufiks -ova- nalazi se u medijalnoj poziciji u odnosu na sufikse -ira- i -isa- po broju stranih glagolskih osnova u kojima je zapažen. Registrovan je u 73 glagola. Najfrekventniji je u glagolima čije su glagolske osnove latinskog - 36 (49,32\%) i francuskog porekla - 24 (32,88\%). U obrađenoj građi prisutan je u nešto manjem broju kod glagolskih osnova grčkog $-5(6,85 \%)$, nemačkog - 4 (5,48\%) i engleskog porekla - $4(5,48 \%)$.

Kao što teorija ističe, a praksa pokazuje, odomaćeni sufiks -isa- prisutan je u glagolskim osnovama stranog porekla, mada, kako naše istraživanje pokazuje, u odnosu na druga dva sufiksa evidentiran je najmanji broj takvih glagola - svega 49. U skladu s očekivanjima, kao i kod prethodna dva sufiksa, i ovaj sufiks najfrekventniji je kod glagolskih osnova latinskog porekla, i to u 34 primera $(69,39 \%)$. Prisutan je i kod glagolskih osnova grčkog - 5 (10,2\%), francuskog - 7 (14,29\%), nemačkog - 2 (4,08\%) i engleskog porekla - 1 (2,04\%), ali, kao što se vidi iz priloženog, sasvim sporadično.

Dakle, nakon što smo i kvantitativno i analitički prikazali građu, zaključujemo da teorija i jezička praksa umnogome korespondiraju. Potvrdili smo da su sufiksi koji su i bili predmet našeg istraživanja prisutni u glagolima čije su osnove stranog porekla. Uočljivo je, takođe, razgraničenje distribucije sufiksa kod pojedinih glagola u srpskom i u hrvatskom jeziku. Još jedna potvrda u prilog ovome zabeležena je u sledećim primerima iz našeg korpusa (primeri glagola sa -ira- registrovani su u tekstovima hrvatskih, a sa -isa- i -ova- u tekstovima srpskih autora):

Žalosni slučaj Tihomira s početka ove priče dosta dobro to ilustrira. (NIN, 14. 7, str. 27, autor: Ante Tomić) - (...) izložba Putevi revolucije - Memorijalni turizam u Jugoslaviji, od 1. jula do 31. avgusta u Muzeju istorije Jugoslavije (koncept: Lana Lovrenčić, Milan Rakita), ilustrovaće kako su spomenici postali deo turističke ponude. (NIN, 21. 7, str. 52, autor: M. V.)

Želi da „generira političku stabilnost, pravnu sigurnost, gospodarski rast, te društvenu solidarnost i uključenost“. (NIN, 21. 7, str. 6, autor: Andrej Plenković). - Dakle, Kamaraš je sirovine plaćao po cenama višim od onih po kojima su kupovale konkurentske čeličane, što je generisalo gubitke u Želežari, tvrdi Milićević... (NIN, 21. 7, str. 31, autor: Pertica Đaković) 
Malo je poznato da je Mostar u poslijeratnoj obnovi unakažen gotovo jednako kao u ratu, tamo su svi projekti koji se realiziraju pod krinkom progresa. (NIN, 21. 7, str. 19, autor: Marko Tomaš) - Da li je Srbija u stanju da taj novac realizuje? (NIN, 21. 7, str. 11, autor: Nikola Tomić)

U istom broju nedeljnika uočena je paralelna distribucija sufiksa -isa-, -ira- i -ova- u istim glagolskim osnovama stranog porekla, što je samo potvrda kontinuiteta u tvorbi ovih glagola, o čemu je pisano u prikazanim radovima iz ranijeg perioda. Za razliku od ovog fleksibilnog normativističkog stava u pogledu tvorbe glagola stranog porekla s posmatranim sufiksima u srpskom standardu, na osnovu onoga što nam je bilo dostupno u literaturi o hrvatskom standardu, možemo zaključiti da je tvorba ovih glagola u okvirima stabilne paradigme.

\section{Zaključak}

Ispitujući glagole čije su generativne baze uglavnom stranog porekla i distribuciju sufiksa -ova-, -isa- ili -ira-, cilj nam je bio da se proveri usklađenost zatečenog stanja sa srpskim standardom, odnosno da li se derivacija sprovodi u skladu s utvrđenim normama srpskog književnog jezika, postoji li neki uticaj hrvatskog, te da li postoji jasna granica između ova dva standarda. U skladu s ciljem, prvo smo predočile propisane norme savremenog srpskog i hrvatskog jezika, a potom ih uporedile sa stanjem dobijenim na temelju rezultata analize i sa ranijim zaključcima o ovoj temi. Korpus za analizu sastojao se od informativnih tekstova iz srpskog nedeljnika. Nakon istraživanja sprovedenog na 241 ekscerpiranom glagolu, potvrđena su 73 glagola izvedena sufiksom -ova-, 49 glagola primeri su izvedeni sufiksom -isa- i 119 glagola izvedeno je sufiksom -ira-. Sufiksi -isa- i -ova- tipični su domaći (odnosno jedan, prvi, odomaćen) sufiksi, dok je sufiks -ira- izdvojen kao strani. Potvrđeno je u našem korpusu da su najbrojniji oni glagoli stranih baza izvedeni sufiksom -ira-, što je u suprotnosti s očekivanjima, budući da srpska derivatologija smatra sufiks -ova- najproduktivnijim. Vidljiv je uticaj hrvatskog standarda u srpskom književnom jeziku, premda ne možemo biti u potpunosti sigurni u smer tih odnosa, budući da je reč o dva genetski ista jezika. Dobijeni rezultati se $u$ velikoj meri slažu sa ranijim istraživanjima - $u$ hrvatskom standardu, koji je prilično hermetičan, i danas je zastupljena uglavnom upotreba sufiksa -ira-, a u srpskom standardu je sve jača tendencija širenja ovog sufiksa i ne postoji izražena potreba za prevođenjem ovog sufiksa sufiksom -ova- ili -isa-. 


\section{Izvori}

Клајн, Иван и Милан Шипка. 2006. Велики речник страних речи и израза. Нови Сад: Прометеј.

Недељне информативне новине (НИН), 2016. бр. 3420 (14.7.2016), 3421 (21.7.2016), 3426 (25.8.2016.), 3427 (01.9.2016). ур. Милан Ћулибрк. Београд: Рингиер Ахел Спрингер.

\section{Literatura}

Barić, Eugenija i dr. 1997. Hrvatska gramatika. Zagreb: Školska knjiga.

Jernej, Josip. 1959. »Glagoli na -irati u XVII i XVIII stoljeću«. Filologija 2: 31 $-40$.

Јоцић, Мирјана. 1970. »Глаголи са суфиксима -иса, -ира, -ова у савременом српскохрватском књижевном језику«. Прилози проучавању језика 5: $121-175$.

Клајн, Иван. 2003. Творба речи у савременом српском језику. Други део - суфиксација и конверзија. Београд: Завод за уџбенике и наставна средства, Институт за српски језик САНУ, Матица српска.

Павловић, Миливој. 1940. »Ширење инфинитива типа -ирати«. Наш језик VII (2-3), с.c.: 81-82.

Ristić-Cvijić, Olga. 1970. »Odnos osnove i nastavka -ovati, -isati, -irati glagola stranog porekla«. Naš jezik XVIII, n.s.: 131-161.

Skok, Petar. 1955-1956. »O sufiksima -isati, -irati i -ovati«. Jezik IV (2): 36-43.

Skok, Petar. 1971-1974. Etimologijski rječnik hrvatskoga ili srpskoga jezika. Priredio za tisak Valentin Putanec. I-IV, Zagreb.

Станојчић, Живојин и Љубомир Поповић. 2002. Граматика српског језика, Шесто прерађено издање. Београд: Завод за уџбенике и наставна средства, 160.

Стевановић, Михаило. 1964-1965. »Неке лексичко-стилске разлике, а не језичке варијанте«. Наш језик XIV (4-5), н.с.: 195-226.

Tošović, Branko i Arno Wonish, ur. 2011. Srpski pogledi na odnose između srpskog, hrvatskog i bošnjačkog jezika I/3. Graz: Institut fur Slawistik der Karl-Franzens-Universitat Graz - Beograd: Beogradska knjiga. 